\title{
The feasibility of wastewater recycling that includes residue from dissolved air flotation within a drinking water treatment plant: case study of Midvaal Water Company, South Africa
}

\author{
Shalene Janse van Rensburg' ${ }^{1}$, Sandra Barnard² and Marina Krüger ${ }^{1}$ \\ ${ }^{1}$ Midvaal Water Company, Farm Buffelsfontein 443 IP, District Klerksdorp, 2570, South Africa \\ ${ }^{2}$ Unit for Environmental Sciences and Management, North-West University, Potchefstroom, 2520, South Africa
}

\begin{abstract}
When purifying water for potable use, wastewater is generated, due to the class of the water treatment plant and the quality of the source water. Midvaal Water Company recycled wastewater that included residue from the dissolved air flotation (DAF), sedimentation and filtration processes in an attempt to save water and reduce costs. The aim of this study was to determine functionality and water quality of such a wastewater recycling system. Samples were collected for analysis, at the sections that contributed to the total wastewater system as well as after various treatment processes. The water quality of these samples was determined, as well as the incidences of water quality failures of the final water, to establish whether the recycle stream that enters the plant together with the source water had any impact on the water quality after the different treatment processes. Data were grouped into periods prior to, during and after recycling to enable comparisons. The water quality of the recycle stream was poorer than that of the source water from the Vaal River with regard to the mean values for total chlorophyll, suspended solids, turbidity and dissolved organic carbon, but the sedimentation process of the wastewater system improved the wastewater quality by drastically reducing total chlorophyll, suspended solids and turbidity. The risk-defined compliance for the final water was excellent ( $\geq 95 \%$ ), despite aluminium, turbidity and total chlorophyll failures of the final water quality during the recycling period. Total chlorophyll was identified as the largest risk during wastewater recycling, especially after the filtration process. It is evident from the data that wastewater recycling, which included wastewater from the DAF, into the main inlet stream of the water treatment plant proved to be effective, based on compliance with national legislation, and had no detrimental impact on overall treatment processes or final water quality.
\end{abstract}

Keywords: dissolved air flotation, sludge balancing dam, total chlorophyll, wastewater recycling, water treatment

\section{INTRODUCTION}

Recent droughts and associated conditions in South Africa have increased water users' awareness of current water demands, which are likely to increase in the future. Deteriorating source water quality together with population increases and high water quality standards have led to greater expenses in the production of drinking water. Drinking water treatment plants generate spent water at various stages depending on the source water's quality and the unit operations involved (Bourgeois et al., 2004). According to Reissmann and Uhl (2006), this has led to numerous efforts to implement water reuse systems in treatment plants all over the world. Sludge produced by water treatment plants is mainly intended for disposal in sanitary landfills but the recycling of spent water produced at different stages of the drinking water treatment process can be applied by water treatment plants to reduce water treatment expenses prior to exploring water reuse systems (Cremades et al., 2018; Wang et al., 2018). Clarified spent filter backwash water has frequently been returned to the inflow of a water treatment plant after a sedimentation process (Reissmann and Uhl, 2006). Many studies related to the generation of potable water treatment waste refer only to the treatment, utilisation or disposal of the residue (Cremades et al., 2018; Herselman, 2013; Zhou et al., 2018). In her Water Research Commission report Herselman (2013) acknowledged that there are still information gaps regarding the characteristics of South African water treatment residue and its beneficial use. To the authors'

*Corresponding author, email: sandra.barnard@nwu.ac.za Received 8 June 2018; accepted in revised form 7 June 2019 knowledge, Midvaal Water Company ('Midvaal' hereafter) is the only water treatment plant in South Africa to also include sludge/wastewater from the dissolved air flotation (DAF) process for recycling. Other bulk water treatment plants recycle wastewater from sedimentation and filtration processes only, such as Virginia and Balkfontein water treatment plants in the Free State Province (Oosthuizen and Janse van Vuuren, 2014).

Midvaal purchases source water from the Department of Water and Sanitation, treats it and sells bulk potable water to the local municipality and surrounding mining industries. In an attempt to reduce operational expenses, Midvaal investigated and implemented an upgraded recycling system for wastewater produced in the water treatment plant (Table 1). Most studies report that the recycled treatment wastewater comprises 2 to $10 \%$ of the plant's throughput (Bourgeois et al., 2004; Curko et al., 2013). The mean daily wastewater flow from the different unit processes was $9.03 \%$ of the maximum operational plant capacity and justified a business case for the recycling of this wastewater. The challenge at the onset of the recycling system was to integrate the sludge from the DAF process, as this contributed to around $46 \%$ of the total wastewater flow per day (Table 1). If the quantity and quality aspects of wastewater can be managed, large quantities of river water can be saved by wastewater recycling, thus lowering input costs, reducing environmental pollution and contributing to water security.

The increased demand for freshwater due to continuous worldwide population increase, coupled with the scarcity of clean water, compels stakeholders to explore alternative water sources, especially in South Africa (Marais et al., 2018). Midvaal piloted the recycling of the waste generated from 
the DAF, sedimentation and filtration processes in June 2013 as an initiative to promote cost-effective water utilisation. Herselman (2013 p. 1) defines water treatment residue (WTR) as 'the accumulated solids or precipitate removed from a sedimentation basin, settling tank, or clarifier in a water treatment plant' but WTR of Midvaal includes the waste from the DAF and filtration processes as well, which renders it more of a wastewater than a residue. However, this is a rare practice in South Africa and the efficacy thereof needs to be determined.

It is imperative that the recycling of wastewater should not contribute to the deterioration of the source water and/or impact on final water quality (with special reference to taste and odours), over and above the benefits of saving water and associated costs. The aims of this study were to determine the functionality and water quality of the recent wastewater recycling system at Midvaal and to determine its effect on the overall treatment processes and associated risks regarding wastewater recycling. The wastewater recycling system was partly placed on hold after February 2016 due to maintenance

Table 1. Wastewater volumes generated per day at the dissolved air flotation (DAF), sedimentation and filtration process units of Midvaal Water Company treatment plant

\begin{tabular}{lc}
\hline Process unit & Volume $\left(\mathrm{m}^{3} /\right.$ day $)$ \\
\hline DAF scum & 5208 \\
DAF sludge & 5220 \\
Sedimentation & 973 \\
Filtration & 11175 \\
Total wastewater (daily flow) & 22576 \\
As \% of 250 ML/day (maximum operational & $9.03 \%$ \\
plant capacity) & \\
\hline
\end{tabular}

needs, and this presented an opportunity for evaluating the failures, benefits and future considerations for this process.

\section{METHODS}

\section{Study site}

The study site was the Midvaal water treatment plant and its wastewater recycling system (Fig. 1). It consists of a network of gravity pipelines, pumping systems and sludge-handling infrastructure. A sludge-thickening plant and pond system has been in operation since 1994 but has limited capacity for treating the total wastewater, especially since the DAF process was implemented in 1997 to address the high algal load in the middle Vaal River and due to the inability of conventional water treatment to effectively remove algae (Janse van Rensburg et al., 2016). An upgrade to Midvaal's treatment plant commenced in 2013 and entailed the provision of infrastructure to transfer wastewater from the DAF process units to a series of dams and, after some retention, to the sludge balancing dam (SBD). The recycling system comprised two inlet dams and a collection dam. The two inlet dams are fed alternately and chlorine is dosed between the inlet dam in use and the collection dam. Chlorine is dosed again in the canal between the overflow of the collection dam towards the SBD by means of sodium hypochlorite tablets; dosing concentrations range from 6 to $10 \mathrm{mg} / \mathrm{L}$. The wastewater from the sedimentation and filtration processes gravitates directly to the SBD without any treatment (Fig. 1). The SBD thus receives the total volume of wastewater produced during plant operation from where the recovered water is pumped to the source water inlet pipe, prior to pre-ozonation.

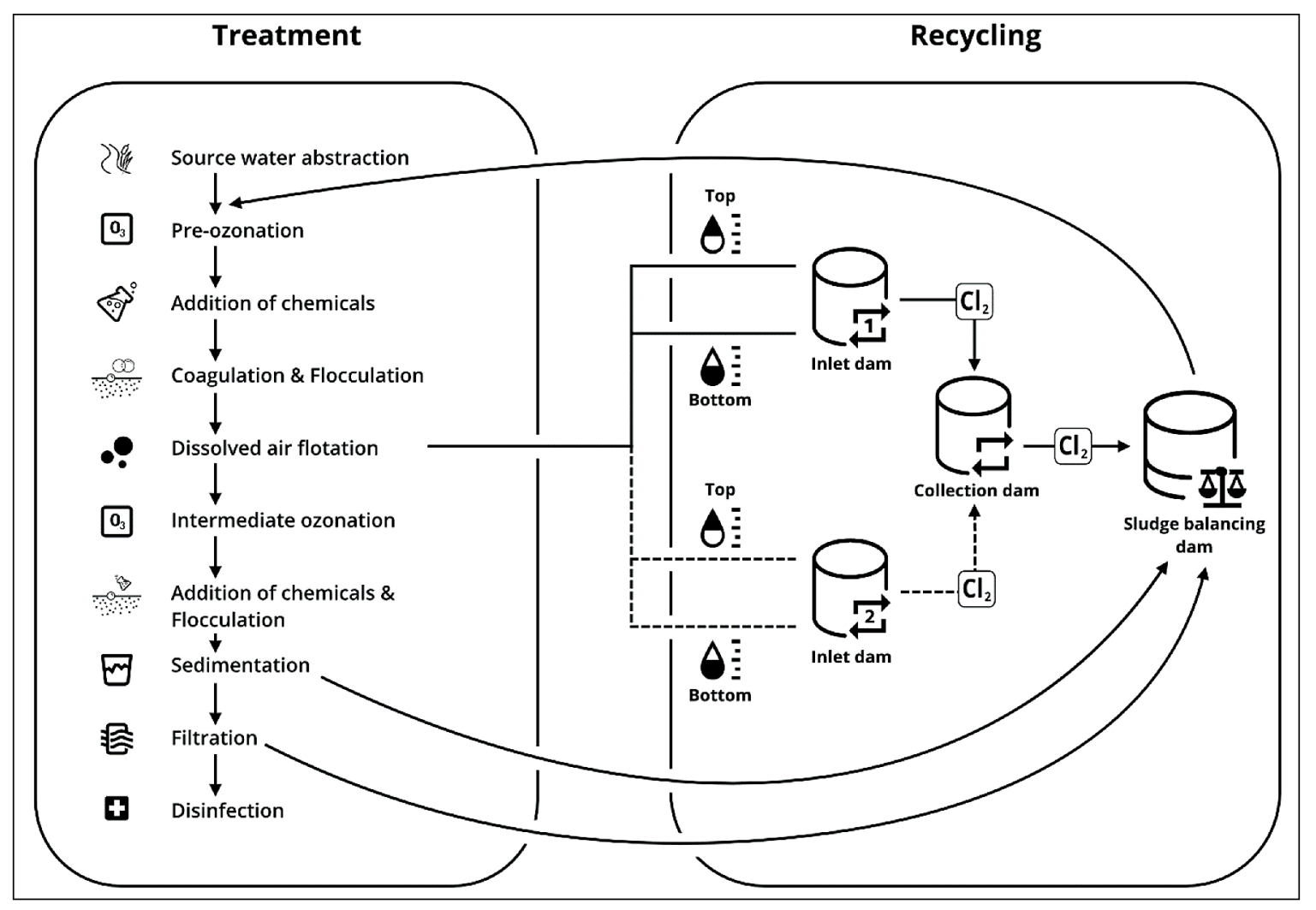

Figure 1. Sequence of the various treatment processes at the Midvaal Water Company and the flow of the wastewater recycling system 
Seven sampling sites were identified at the onset of the wastewater recycling system in 2013 (Table 2, Fig. 1) to determine the water quality of the spent water generated during each of the targeted treatment processes.

To determine the impact of the recycled water (from the SBD) on the water treatment plant, water quality data from the river (source water), after DAF, after west sedimentation and after east sedimentation, were collected and statistically analysed. The study period included a year prior to the implementation of the recycling system (June 2012 to June 2013), the operational period of the recycling system (June 2013 to February 2016) and a year after the termination of the wastewater recycling system (February 2016 to February 2017).

\section{Sampling regime}

Midvaal's process controllers sampled the DAF top, DAF bottom, east wastewater, west wastewater and the collection dam overflow on a weekly basis from June 2013 to February 2016. Midvaal Water Company Scientific Services sampled water from the river, recycle stream, after DAF, after sedimentation and after filtration on a daily basis. Data reports for the daily samples were generated from the Scientific Services' Laboratory Information Management System from a year prior to the implementation of the recycling system to a year after its termination for statistical analyses (i.e. June 2012 to February 2017). The wastewater from the east and west wastewaters was recycled from February 2016 to February 2017. The samples were chemically and microbiologically analysed by Midvaal Water Company Scientific Services for the 10 determinants listed in Table 3. Samples of the final drinking water were submitted to the CSIR every second month for analyses of protozoan parasites (Cryptosporidium oocysts and Giardia cysts). Midvaal Water Company Scientific Services has been an accredited South African National Accreditation System (SANAS) testing laboratory (T0132) since 2002 based on the International Organisation for Standardisation 17025 (SANAS, 2018).

\section{Statistical analyses}

Microsoft Excel was used to compile column charts to illustrate differences in unit values of determinants for the different sampling sites. Statistica software (version 13) was used to determine descriptive statistics (mean, standard deviation, variance and confidence interval) for all determinants (Tibco Inc, 2017). The Shapiro-Wilks test for normality was used to determine whether the data were distributed parametrically. Since the data did not meet the assumptions of normality in the distribution of all variables, the Kruskal-Wallis analysis of variance (nonparametric statistics) for comparing multiple independent groups was used to determine differences between unit values of determinants measured after treatment process prior to, during and after the implementation of the wastewater recycling system. Results that were below the quantification limit were divided by two to be included in data processing, whereas those that were above the quantification limit were multiplied by two.

\section{RESULTS}

\section{Water quality of wastewater}

The mean total chlorophyll, suspended solids, turbidity, dissolved organic carbon, $\mathrm{pH}$ and electrical conductivity (EC) for each section of the wastewater recycling system are
Table 2. Sampling sites at the Midvaal Water Company wastewater recycling system

\begin{tabular}{|c|c|c|}
\hline Site name & Abbreviation & Description \\
\hline DAF top & DAF-T & $\begin{array}{l}\text { Sludge is withdrawn at top of } \\
\text { DAF units due to flotation and } \\
\text { transferred to inlet dam }\end{array}$ \\
\hline DAF bottom & DAF-B & $\begin{array}{l}\text { Sludge is withdrawn at bottom of } \\
\text { DAF units due to sedimentation } \\
\text { and transferred to inlet dam }\end{array}$ \\
\hline East sludge & ES & $\begin{array}{l}\text { Combined wastewater from east } \\
\text { side sedimentation and filtration } \\
\text { of plant transferred to sludge } \\
\text { balancing dam (SBD) }\end{array}$ \\
\hline West sludge & WS & $\begin{array}{l}\text { Combined wastewater from west } \\
\text { side sedimentation and filtration } \\
\text { of plant transferred to SBD }\end{array}$ \\
\hline $\begin{array}{l}\text { Collection } \\
\text { dam } \\
\text { overflow }\end{array}$ & $\mathrm{CDO}$ & $\begin{array}{l}\text { Second retention dam that } \\
\text { overflows into canal towards SBD }\end{array}$ \\
\hline $\begin{array}{l}\text { Recycle } \\
\text { stream }\end{array}$ & RS & $\begin{array}{l}\text { Water from SBD combined with } \\
\text { river water prior to any treatment }\end{array}$ \\
\hline Vaal River & $\mathrm{R}$ & $\begin{array}{l}\text { Source water abstracted from middle } \\
\text { Vaal River for treatment prior to } \\
\text { introduction of recycle stream }\end{array}$ \\
\hline
\end{tabular}

compared in Figs. 2a and 2b. The wastewater from the DAF top had means of $9825 \mu \mathrm{g} / \mathrm{L}$ total chlorophyll, $3497 \mathrm{mg} / \mathrm{L}$ suspended solids, 2457 NTU turbidity and $18 \mathrm{mg} / \mathrm{L}$ dissolved organic carbon, whereas the DAF bottom had means of $9148 \mu \mathrm{g} / \mathrm{L}$ total chlorophyll, $4693 \mathrm{mg} / \mathrm{L}$ suspended solids, $4880 \mathrm{NTU}$ turbidity and $33 \mathrm{mg} / \mathrm{L}$ dissolved organic carbon. The quality of the wastewater (sludge from DAF units) that
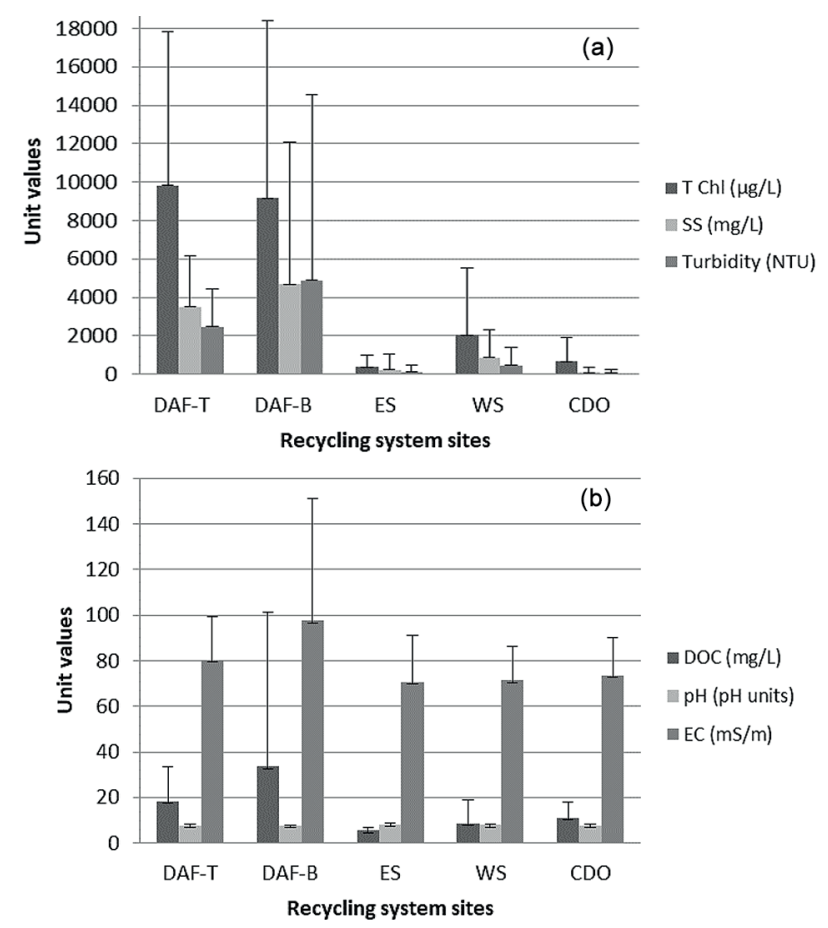

Figure 2. (a \& b) Mean total chlorophyll (T Chl), suspended solids (SS), turbidity (NTU), dissolved organic carbon (DOC), pH and electrical conductivity $(\mathrm{EC})$ concentrations with standard deviation error bars of the wastewater sampled at various sites for the water recycling system from 5 June 2013 to 3 February 2016 
Table 3. Determinants in the datasets that were statistically analysed in this study; method number refers to the South African National Accreditation System (SANAS)-accredited method as indicated on the facility's schedule of accreditation

\begin{tabular}{|c|c|c|c|}
\hline Determinant & Unit & Methods/Instruments & Method number \\
\hline $\mathrm{pH}$ & $\mathrm{pH}$ units & Determined with a pH electrode & WL1 \\
\hline Electrical conductivity & $\mathrm{mS} / \mathrm{m}$ & Determined with an electrical conductivity electrode & WL2 \\
\hline Turbidity & NTU & Determined with a turbidity meter & WL3 \\
\hline Suspended solids & $\mathrm{mg} / \mathrm{L}$ & Gravimetric method & WL5 \\
\hline Aluminium & $\mathrm{mg} / \mathrm{L}$ & Inductively coupled plasma optical emission spectroscopy & ICP1-A-1 \\
\hline Total organic carbon & $\mathrm{mg} / \mathrm{L}$ & Determined by a persulfate-ultraviolet oxidation method & AAL5 \\
\hline $\begin{array}{l}\text { Spectral absorbance } \\
\text { coefficient } 254\end{array}$ & $\mathrm{~m}^{-1}$ & Absorption method & AL6* \\
\hline Chlorophyll- $a$ & $\mu g / L$ & Extraction and absorption method & $A L 1 *$ \\
\hline Total chlorophyll & $\mu \mathrm{g} / \mathrm{L}$ & $\begin{array}{l}\text { Determined by means of the Sartory (Swanepoel et al., 2008) } \\
\text { extraction method }\end{array}$ & AL2 \\
\hline E. coli & MPN/ $100 \mathrm{~mL}$ & Colilert & BL5-1 \\
\hline $\begin{array}{l}\text { Cryptosporidium oocysts } \\
\text { and Giardia cysts }\end{array}$ & Count/10L & Analyses performed by the CSIR & Outsourced \\
\hline
\end{tabular}

*indicates methods that are not SANAS-accredited

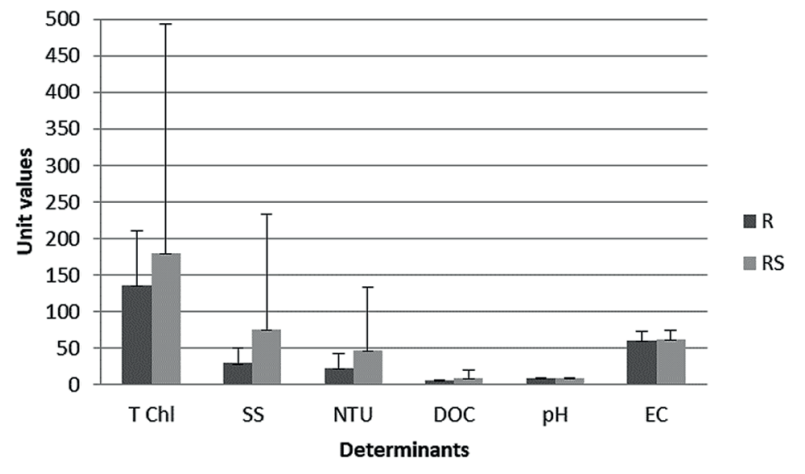

Figure 3. Mean total chlorophyll (T Chl), suspended solids (SS), turbidity (NTU), dissolved organic carbon (DOC), $\mathrm{pH}$ and electrical conductivity (EC) concentrations with standard deviation error bars for the Vaal River (R) and recycle stream (RS) from 5 June 2013 to 3 February 2016

overflowed from the collection dam to the SBD improved significantly, with means of $662 \mu \mathrm{g} / \mathrm{L}$ total chlorophyll, $93 \mathrm{mg} / \mathrm{L}$ suspended solids, 65 NTU turbidity and $11 \mathrm{mg} / \mathrm{L}$ dissolved organic carbon. The total chlorophyll, suspended solids and turbidity of the west wastewater were noticeably higher than those of the east wastewater. The $\mathrm{pH}$ and EC for each section's wastewater varied very little over the study period.

Figure 3 illustrates the water quality of the recycle stream compared to the water quality of the middle Vaal River. The mean $\mathrm{pH}$ and $\mathrm{EC}$ of the recycle stream and river differed significantly according to Kruskal-Wallis although these difference are small ( 8.4 vs. $8.7 \mathrm{pH}$ and 62 vs. $60 \mathrm{mS} / \mathrm{m}$ electrical conductivity for recycle stream and river, respectively). The mean values of total chlorophyll (179 vs. $136 \mu \mathrm{g} / \mathrm{L}$ ), suspended solids ( 75 vs. $29 \mathrm{mg} / \mathrm{L}$ ), turbidity (46 vs. $22 \mathrm{NTU}$ ) and dissolved organic carbon ( $8.3 \mathrm{vs.}$ $5.7 \mathrm{mg} / \mathrm{L}$ ) of the recycle stream were higher than that of the river water but only suspended solids and turbidity differed significantly according to Kruskal-Wallis with $p$-values $<0.05$. The total chlorophyll concentration in the recycle stream ranged from 11 to $6451 \mu \mathrm{g} / \mathrm{L}$. The water quality of the recycle stream that originated from the SBD represents an improvement compared to that from the collection dam overflow in terms of total chlorophyll (662 vs. $179 \mu \mathrm{g} / \mathrm{L}$ ), suspended solids ( $93 \mathrm{vs.} 75 \mathrm{mg} / \mathrm{L}$ ), turbidity (65 vs. 46 NTU) and dissolved organic carbon (11 vs. $8.3 \mathrm{mg} / \mathrm{L})$. This observed improvement can be ascribed to a dilution effect when water from the collection dam overflow was combined with higher-quality water from the east and west wastewater already present in the SBD.

\section{Final water quality failures}

To establish whether the recycle stream had any impact on the water quality of the final water produced by the plant, the incidences of water quality failures for the final water were determined. Failures were determined as noncompliance to South African National Standard (SANS) 241:2015. SANS 241:2015 requires aluminium concentrations to comply with a limit of $\leq 0.3 \mathrm{mg} / \mathrm{L}$ regarding operational risks and turbidity with limits of $\leq 1 \mathrm{NTU}$ and $\leq 5 \mathrm{NTU}$ for operational and aesthetic risks, respectively. Even though there is no national limit for total chlorophyll, Midvaal has an internal limit of $\leq$ $1.0 \mu \mathrm{g} / \mathrm{L}$ in the final water (Janse van Rensburg et al., 2016). Aluminium, turbidity and total chlorophyll failures occurred during the entire study period and most failures for all three of these determinants were recorded when the recycling system was in operation (Table 4). Despite these failures, the water quality of the final water during the addition of the recycle stream still complied at $\geq 95 \%$ for aluminium and turbidity.

\section{Effect of wastewater recycling system on various treatment processes}

Mean aluminium concentrations increased over time in the river and displayed slight increases after DAF and west and east sedimentation during the wastewater recycling process during the same time period (Fig. 4). However, all mean concentrations were below the limit of $\leq 0.3 \mathrm{mg} / \mathrm{L}$ at all times.

The increased turbidity levels in the river during the study period were also reflected in the increased turbidity measured after DAF, but the mean turbidity levels remained below 4 and 3 NTU after the west and east sedimentation processes, respectively (Fig. 5).

Mean total chlorophyll concentrations in the river decreased during the study period. This trend was also visible after the west and east sedimentation processes. Total chlorophyll removal was best achieved after DAF during wastewater recycling (Fig. 6).

Mean total organic carbon concentrations were consistently higher in the river and during the wastewater recycling process at all study sites (Fig. 7). 
Table 4. Final drinking water failures from June 2012 to February 2017, considering that the recycle stream was in operation from June 2013 to February 2016 as well as the associated risk-defined compliances, as prescribed by South African National Standard 241:2015

\begin{tabular}{|c|c|c|c|c|c|c|}
\hline & \multirow{2}{*}{ Pre-recycling } & \multicolumn{4}{|c|}{ During recycling } & \multirow{2}{*}{ Post-recycling } \\
\hline & & From June 2013 & 2014 & 2015 & To February 2016 & \\
\hline \multicolumn{7}{|l|}{ Aluminium } \\
\hline Total number of analyses & 149 & 82 & 147 & 149 & 14 & 143 \\
\hline Aluminium failures & 0 & 1 & 1 & 4 & 0 & 1 \\
\hline$\%$ Compliance & 100 & 99 & 99 & 97 & 100 & 99 \\
\hline Operational compliance & $\begin{array}{l}(\geq 95 \%)- \\
\text { Excellent }\end{array}$ & $\begin{array}{l}(\geq 95 \%)- \\
\text { Excellent }\end{array}$ & $\begin{array}{l}(\geq 95 \%)- \\
\text { Excellent }\end{array}$ & $\begin{array}{l}(\geq 95 \%)- \\
\text { Excellent }\end{array}$ & $\begin{array}{l}(\geq 95 \%)- \\
\text { Excellent }\end{array}$ & $\begin{array}{l}(\geq 95 \%)- \\
\text { Excellent }\end{array}$ \\
\hline \multicolumn{7}{|l|}{ Turbidity } \\
\hline Total number of analyses & 357 & 203 & 361 & 360 & 34 & 367 \\
\hline Turbidity failures & 6 & 6 & 19 & 6 & 0 & 9 \\
\hline$\%$ Compliance & 98 & 97 & 95 & 98 & 100 & 98 \\
\hline Operational compliance & $\begin{array}{l}(\geq 95 \%)- \\
\text { Excellent }\end{array}$ & $\begin{array}{l}(\geq 95 \%)- \\
\text { Excellent }\end{array}$ & $\begin{array}{l}(\geq 95 \%)- \\
\text { Excellent }\end{array}$ & $\begin{array}{l}(\geq 95 \%)- \\
\text { Excellent }\end{array}$ & $\begin{array}{l}(\geq 95 \%)- \\
\text { Excellent }\end{array}$ & $\begin{array}{l}(\geq 95 \%)- \\
\text { Excellent }\end{array}$ \\
\hline Aesthetic compliance & $\begin{array}{l}(\geq 95 \%)- \\
\text { Excellent }\end{array}$ & $\begin{array}{l}(\geq 95 \%)- \\
\text { Excellent }\end{array}$ & $\begin{array}{l}(\geq 95 \%)- \\
\text { Excellent }\end{array}$ & $\begin{array}{l}(\geq 95 \%)- \\
\text { Excellent }\end{array}$ & $\begin{array}{l}(\geq 95 \%)- \\
\text { Excellent }\end{array}$ & $\begin{array}{l}(\geq 95 \%)- \\
\text { Excellent }\end{array}$ \\
\hline \multicolumn{7}{|l|}{ Total chlorophyll } \\
\hline Total number of analyses & 242 & 138 & 224 & 237 & 21 & 235 \\
\hline Total chlorophyll failures & 22 & 44 & 37 & 2 & 0 & 15 \\
\hline$\%$ Compliance & 91 & 68 & 83 & 99 & 100 & 94 \\
\hline
\end{tabular}

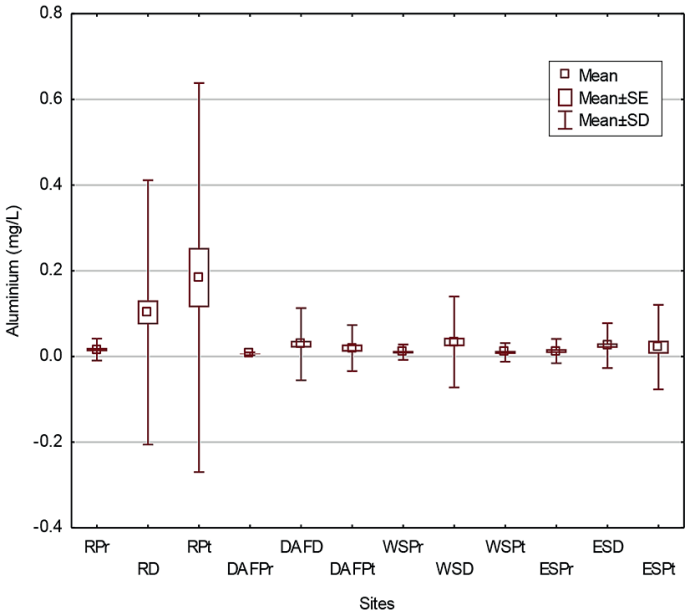

Figure 4. Aluminium concentrations of the Vaal River, after dissolved air flotation (DAF), after west and east sedimentation for the periods prior to, during and after implementation of wastewater recycling; $\mathrm{RPr}, \mathrm{RD}$ and RPt: river pre, during and post recycling system; DAFPr, DAFD and DAFPt: DAF pre, during and post recycling system; WSPr, WSD and WSPt: west sedimentation pre, during and post recycle system; ESPr, ESD and ESPt: east sedimentation pre, during and post recycling system

Mean E. coli concentrations continuously increased over time in the river and after DAF but remained at $\leq 10 \mathrm{MPN} / 100 \mathrm{~mL}$ after the west and east sedimentation processes (Fig. 8).

The Kruskal-Wallis test was applied to data collected for $\mathrm{pH}, \mathrm{EC}$, spectral absorbance coefficient 254 and chlorophyll- $a$, but no significant differences between unit values of these determinants for the treatment processes prior to, during and after implementation of the wastewater recycling system were detected.

The water quality after the filtration process was not included in Figs. 4 to 8 as differences between periods prior

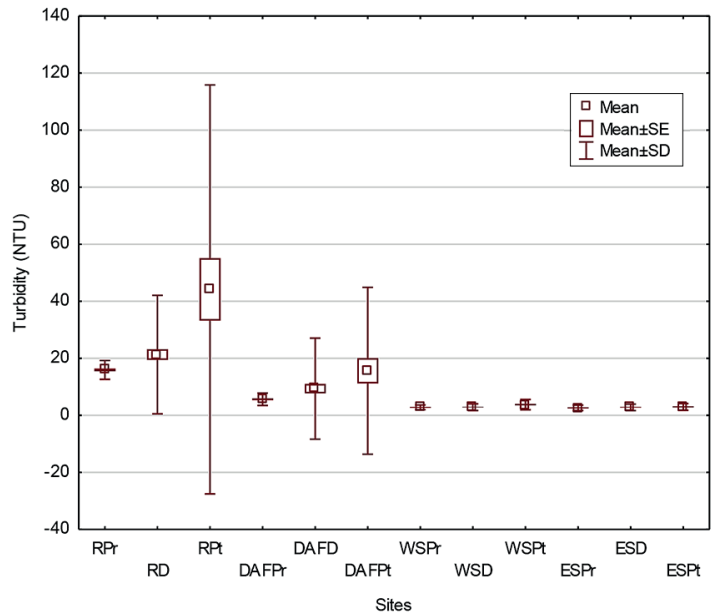

Figure 5. Turbidity levels of the Vaal River, after dissolved air flotation (DAF), after west and east sedimentation for the periods prior to, during and after implementation of wastewater recycling; RPr, RD and RPt: river pre, during and post recycling system; DAFPr, DAFD and DAFPt: DAF pre, during and post recycling system; WSPr, WSD and WSPt: west sedimentation pre, during and post recycle system; ESPr, ESD and ESPt: east sedimentation pre, during and post recycling system

to, during and after implementation of wastewater recycling were negligible and this water represents the final drinking water, the quality of which is addressed in Tables 4 and 5 . In Table 5 the mean total chlorophyll was highest after west and east filtration during the recycling process but at levels and concentrations that complied with limits. Maximum $\mathrm{pH}$ levels and total chlorophyll concentrations exceeded limits throughout the study period except for the maximum total chlorophyll of the west filtration after recycling.

No Cryptosporidium oocysts or Giardia cysts were detected in the final water prior to, during or after recycling. 


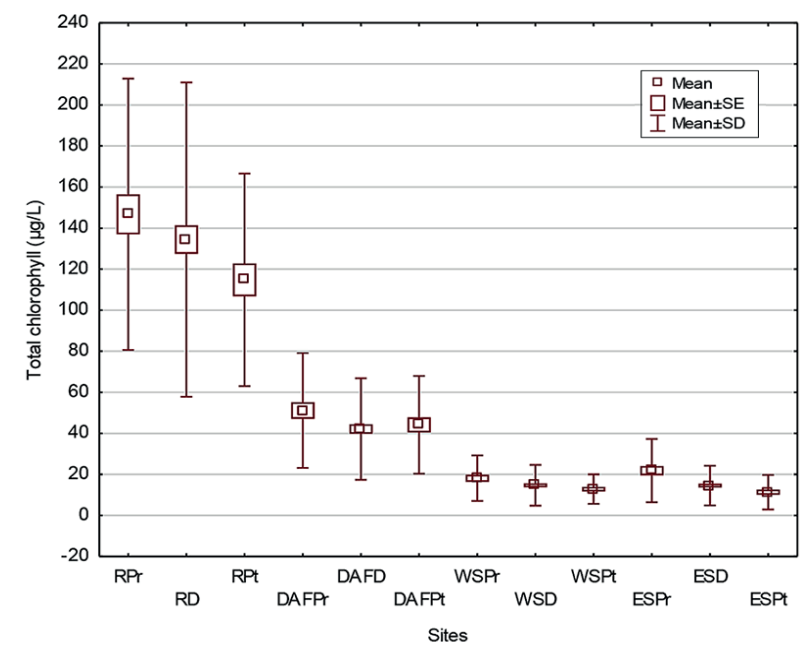

Figure 6. Total chlorophyll concentrations in the Vaal River, after dissolved air flotation (DAF), after west and east sedimentation for the periods prior to, during and after implementation of wastewater recycling; RPr, RD and RPt: river pre, during and post recycling system; DAFPr, DAFD and DAFPt: DAF pre, during and post recycling system; WSPr, WSD and WSPt: west sedimentation pre, during and post recycle system; ESPr, ESD and ESPt: east sedimentation pre, during and post recycling system

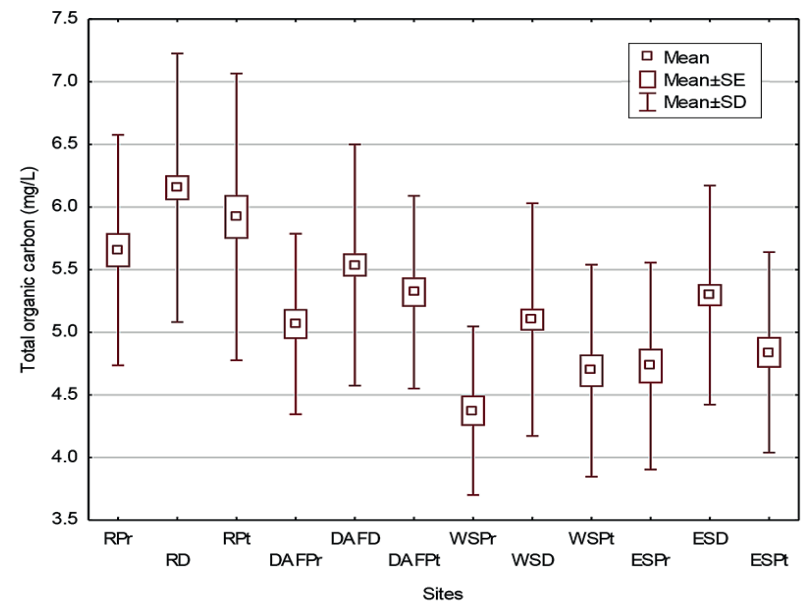

Figure 7. Total organic carbon concentrations of the Vaal River, after dissolved air flotation (DAF), after west and east sedimentation for the periods prior to, during and after implementation of wastewater recycling; $\mathrm{RPr}, \mathrm{RD}$ and $\mathrm{RPt}$ : river pre, during and post recycling system; DAFPr, DAFD and DAFPt: DAF pre, during and post recycling system; WSPr, WSD and WSPt: west sedimentation pre, during and post recycle system; ESPr, ESD and ESPt: east sedimentation pre, during and post recycling system

\section{DISCUSSION}

Concerns about water recycling with regards to microorganisms (such as micro-algae and E. coli), heavy metals and increasing turbidity are some reasons why many water treatment plants have not returned wastewater to the water treatment process. Reissmann and Uhl (2006) were concerned about the recycling of precursors for disinfection by-products. During this investigation the sludge from DAF largely contributed to the poor water quality of the water recycling system. The total chlorophyll, suspended solids, turbidity and dissolved organic carbon of the

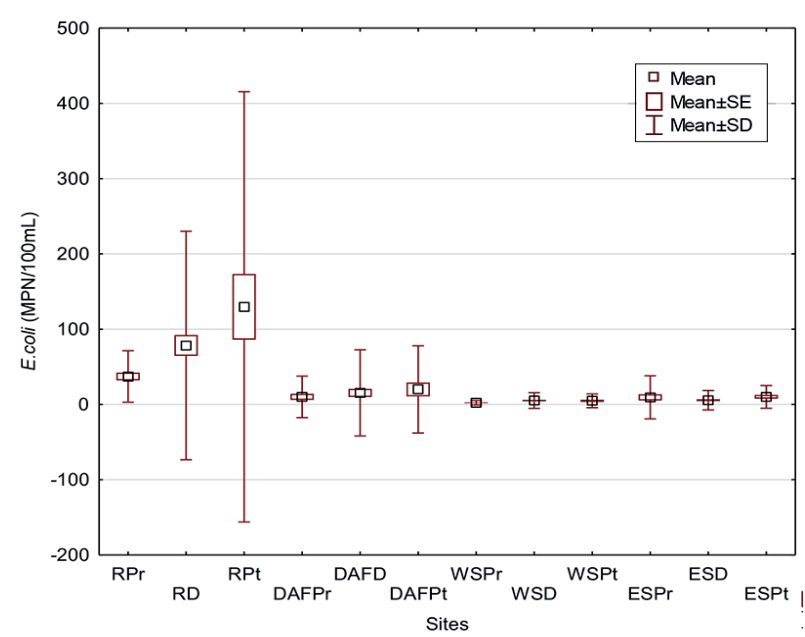

Figure 8. E. coli concentrations of the Vaal River, after dissolved air flotation (DAF), after west and east sedimentation for the periods prior to, during and after implementation of wastewater recycling; $\mathrm{RPr}, \mathrm{RD}$ and RPt: river pre, during and post recycling system; DAFPr, DAFD and DAFPt: DAF pre, during and post recycling system; WSPr, WSD and WSPt: west sedimentation pre, during and post recycle system; ESPr, ESD and ESPt: east sedimentation pre, during and post recycling system

sludge transferred from the DAF top and bottom to the inlet dam were extremely high (Figs. $2 \mathrm{a}$ and $2 \mathrm{~b}$ ), but the concentrations of these determinants for the wastewater that overflowed from the collection dam to the SBD improved significantly. The effect of retention to allow for the settling of suspended matter in the holding and collection dams was noticeable. Haarhoff et al. (2001) also concluded that the turbidity of the supernatant on the sludge (sedimentation wastewater) and washwater (filtration wastewater) at the Vaalkop treatment plant was mostly lower than that of source water abstracted from the Vaalkop dam. Bourgeois et al. (2004) have shown that optimising the monovalent: divalent cation balance ratio can improve the quality of combined filtered backwash wastewater by sedimentation. The west and east sedimentation and filtration seemed to be equally effective when values were compared during recycling and did not verify the poorer water quality of the west sludge in Fig. 2a.

The total chlorophyll, suspended solids and turbidity of the recycle stream were identified as risks due to extreme concentrations (Fig. 3) together with the outcomes from Janse van Rensburg et al.'s (2016) study, which confirmed that increasing total chlorophyll concentrations and turbidity spikes were the main source-water quality challenges for Midvaal. Haarhoff et al. (2001) stated that the rate of solids production, associated with turbidity levels in wastewater, at treatment plants treating inland surface water, are highly variable and occasionally reach extremely high peaks (Haarhoff et al., 2001).

Aluminium is introduced as a water treatment chemical (aluminium sulfate) and concentrations were below the required limit for drinking water in the river despite the observed increase during 2012-2017 (Fig. 4). During the time that aluminium failures were recorded in the final water, neither aluminium concentrations nor turbidity levels were water quality concerns in the river water and it could be ascribed to the dosing of aluminium sulfate during the water treatment process. The turbidity levels of both the river and 
recycle stream were not significantly high during times when turbidity failures were recorded and no pattern/correlation could be established. Moreover, the turbidity levels of the recycle stream were not necessarily higher than those of the river during times when turbidity failures were recorded. The mean $\mathrm{pH}$ of the river was 9.0 and the median 9.1 during times when turbidity failures occurred. The aluminium and turbidity failures only corresponded once (25 February 2015); the same was true for aluminium, turbidity and total chlorophyll failures (14 July 2014).

The total chlorophyll concentrations of the river prior to and after the wastewater recycling ranged from 57 to $373 \mu \mathrm{g} / \mathrm{L}$ and from 68 to $196 \mu \mathrm{g} / \mathrm{L}$, respectively, during times when failures were recorded. Total chlorophyll concentrations of the river and recycle stream ranged from 57 to $393 \mu \mathrm{g} / \mathrm{L}$ and from 15 to $6451 \mu \mathrm{g} / \mathrm{L}$, respectively, during recycling at times when failures were recorded and no seasonal correlation could be confirmed. Total chlorophyll concentrations were highest after west and east filtration during the recycling process. The total chlorophyll concentrations increased from 0.6 to $0.8 \mu \mathrm{g} / \mathrm{L}$ after both west and east filtration during the wastewater recycling and is a cause for concern as it is close to the limit of $\leq 1.0 \mu \mathrm{g} / \mathrm{L}$ (Table 5). These total chlorophyll concentrations after west and east filtration do not correspond with the decreasing trends depicted in Fig. 6 after west and east sedimentation. The impact on the filtration process and irregular failures in terms of total chlorophyll have to be monitored and managed closely during wastewater recycling, especially since no particular correlation could be identified from this research. In the event of taste and odour episodes, recycling has to be terminated until the situation is resolved.

Total organic carbon concentrations in the river peaked during the recycling period, but all mean total organic carbon concentrations, including those for the river, were below the limit of $\leq 10 \mathrm{mg} / \mathrm{L}$ (Fig. 7) and complied with SANS 241:2015 requirements at all times (SABS, 2015). E. coli and turbidity in the river displayed similar increasing trends (Figs. 5 and 8, respectively) as opposed to the decreasing total chlorophyll concentrations (Fig. 6). Turbidity can inhibit photosynthesis by blocking sunlight and, as algae decay, the decomposition process allows organic particles to release as suspended solids and contribute to turbidity (Fondriest Environmental, Inc., 2014).

\section{Supplementary benefits of wastewater recycling}

The source water tariff for 2016 was $\mathrm{R} 3.22 / \mathrm{kL}$ which results in an average saving of approximately R 27 million per year when calculated:

$22576 \mathrm{~kL} /$ day (Table 1) × 365 (days per year) $\times$ R 3.22/kL $(2016$ water tariff) $=$ R 26533572 .
Wastewater recycling systems have several benefits in addition to reducing water treatment expenses. Such a system allows for suspended solids to settle out and thus contributes to turbidity reduction (Fig. 2a). Natural microbiological processes result in improved microbiological quality of the wastewater due to disinfection via sunlight. Furthermore, the SBD attenuates the flow rate of the recycled stream, which results in more consistent and controllable introduction of wastewater into the river water inlet stream. The health-related risks of recycling wastewater are considered manageable as the recycle stream is introduced at the beginning of the treatment process, prior to pre-ozonation and subsequent treatment processes to ultimately produce potable water for consumers. Furthermore, Cornwell and MacPhee (2001) reported that only when spent filter backwash water of up to $20 \%$ volume was recycled was Cryptosporidium removal affected.

\section{Future considerations regarding wastewater recycling}

In light of the findings of this study, several points regarding the implementation of wastewater recycling systems should be considered. Periodic blue-green algal blooms and poor source water quality require temporary termination of the wastewater recycling system, as this has a negative impact on the treated water quality if recycled, e.g., in terms of taste and odour. Water from the recycle dams at Virginia and Balkfontein water treatment plants was discharged into the Vaal River during prevalent algal blooms (Oosthuizen and Janse van Vuuren, 2014). Extension of the dam surface area is necessary as provision for the total wastewater flow to curtail recycling of poor-quality water plugs and prevent possible discharge into the environment. Anaerobic/ anoxic conditions may develop in the dams and some form of mechanical agitation/aeration has to be considered for the future. Additional disposal sites are necessary for dry sludge, which would subsequently require further analyses and classification. Microbiological monitoring of the recycle stream could expand to include contaminants of emerging concerns, such as endocrine-disrupting compounds and persistent organic pollutants. Trihalomethane formation monitoring is required due to the high organic load (dissolved organic carbon) in the wastewater recycling system and the dosing of chlorine at two points (Fig. 1).

\section{CONCLUSION}

It is evident from the available data that wastewater recycling, which included wastewater from the DAF plant, into the main inlet stream of the water treatment plant proved to be effective based on SANS 241:2015 compliance and had no detrimental impact on overall treatment processes or final water quality.

Table 5. Descriptive statistics for turbidity levels and total chlorophyll concentrations after west and east filtration processes, where failures are shaded; WFPr, WFD and WFPt: west filtration pre, during and post recycle system; EFPr, EFD and EFPt: east filtration pre, during and post recycle system

\begin{tabular}{|c|c|c|c|c|c|c|c|c|}
\hline & \multicolumn{4}{|c|}{ Turbidity (NTU) } & \multicolumn{4}{|c|}{ Total chlorophyll ( $\mu \mathrm{g} / \mathrm{L})$} \\
\hline & Mean & Minimum & Maximum & $\begin{array}{l}\text { Standard } \\
\text { deviation }\end{array}$ & Mean & Minimum & Maximum & $\begin{array}{l}\text { Standard } \\
\text { deviation }\end{array}$ \\
\hline WFPr & 0.5 & 0.2 & 1.0 & 0.2 & 0.6 & 0.3 & 2.3 & 0.5 \\
\hline WFD & 0.6 & 0.2 & 1.9 & 0.3 & 0.8 & 0.3 & 14 & 1.4 \\
\hline WFPt & 0.6 & 0.4 & 1.0 & 0.2 & 0.4 & 0.3 & 0.7 & 0.2 \\
\hline EFPr & 0.6 & 0.3 & 2.0 & 0.3 & 0.6 & 0.1 & 3.0 & 0.6 \\
\hline EFD & 0.7 & 0.2 & 2.4 & 0.3 & 0.8 & 0.3 & 3.7 & 0.6 \\
\hline EFPt & 0.7 & 0.3 & 2.3 & 0.4 & 0.4 & 0.3 & 1.5 & 0.3 \\
\hline
\end{tabular}


The wastewater recycling system operated successfully and was cost-effective due to reduced river water purchases. Total chlorophyll was identified as the most prominent risk when wastewater is recycled due to the high concentration in both the river and recycle stream, borderline concentrations of $0.8 \mu \mathrm{g} / \mathrm{L}$ after filtration during recycling and failures during recycling. Water quality of the sludge from DAF units improved significantly after it was subjected to retention in the dam system and dilution with wastewater from the sedimentation and filtration processes. Final water quality failures recorded for aluminium, turbidity and total chlorophyll occurred mostly during the recycling period, but the risk-defined compliances were calculated and categorized as excellent $(\geq 95 \%)$ for both aluminium and turbidity in the periods prior to, during and after wastewater recycling. The total chlorophyll compliance was $94 \%$ in the year prior to the implementation of the wastewater recycling system, $88 \%$ during recycling and $96 \%$ in the year after recycling. The findings of this case study are, however, based on retrospective data evaluation and could not take all of the factors that contributed to water quality on the Midvaal treatment plant into account.

\section{ACKNOWLEDGEMENTS}

Midvaal Water Company is gratefully acknowledged for sharing information and data. We would like to thank $\mathrm{Mr}$ CF de Villiers (Plant Foreman - Midvaal Water Company) and Prof J Haarhoff for their valuable contributions and discussions, Mr A Marais for assistance with the design of the illustration and Ms E Harris for editorial input. We would like to thank the National Research Foundation (UID: 296036) for financial support.

\section{REFERENCES}

BOURGEOIS JC, WALSH ME and GAGNON GA (2004) Treatment of drinking water residuals: comparing sedimentation and dissolved air flotation performance with optimal cation ratios. Water Res. 38 1173-1182. https://doi.org/10.1016/j.watres.2003.11.018.

CORNWELL DA and MACPHEE MJ (2001) Effects of spent filter backwash recycle on Cryptosporidium removal. J. Am. Water Works Assoc. 93 (4) 153-162. https://doi. org/10.1002/j.1551-8833.2001.tb09185.x.

CREMADES LV, CUSIDÓ JA and ARTEAGA F (2018) Recycling of sludge from drinking water treatment as ceramic material for the manufacture of tiles. J. Clean. Prod. 201 1071-1080. https://doi. org/10.1016/j.jclepro.2018.08.094.

ĆURKO J, MIJATOVIĆ I, RUMORA D, CRNEK V, MATOŠIĆ M and NEŽIĆ M (2013) Treatment of spent filter backwash water from drinking water treatment with immersed ultrafiltration membranes. Desalin. Water Treat. 51 (25-27) 4901-4906. https:// doi.org/10.1080/19443994.2013.774142.
FONDRIEST ENVIRONMENTAL, INC. (2014) Turbidity, Total Suspended Solids and Water Clarity. Fundamentals of Environmental Measurements. URL: https://www.fondriest.com/ environmental-measurements/parameters/water-quality/turbiditytotal-suspended-solids-water-clarity/ (Accessed 7 May 2018).

HAARHOFF J, VAN HEERDEN P and VAN DER WALT M (2001) Sludge and washwater management strategies for the Vaalkop water treatment plant. Water Sci. Technol. 44 (6) 73-80. https://doi. org/10.2166/wst.2001.0344.

HERSELMAN JE (2013) Guidelines for the utilisation and disposal of water treatment residues. WRC Report No. TT559/13. Water Research Commission, Pretoria.

JANSE VAN RENSBURG S, BARNARD S and KRÜGER M (2016) Challenges in the potable water industry due to changes in source water quality: case study of Midvaal Water Company, South Africa. Water SA 42 (4) 633-640. http://dx.doi.org/10.4314/wsa.v42i4.14.

MARAIS SS, NDLANGAMANDLA NG, BOPAPE DA, STRYDOM WF, MOYO W, CHAUKURA N, KUVAREGA AT, DE KOCK L, MAMBA BB, MSAGATI TAM and co-authors (2018) Natural Organic Matter (NOM) in South African Waters. WRC Report No. 2468/1/18. Water Research Commission, Pretoria.

OOSTHUIZEN MGJ and JANSE VAN VUUREN S (2014) Changes in density and composition of algal assemblages in certain unit processes of two South African water purification plants. Afr. J. Aquat. Sci. 39 (3) 313-326. https://doi.org/10.2989/16085914.2014. 957638.

REISSMANN FG and UHL W (2006) Ultrafiltration for the reuse of spent filter backwash water from drinking water treatment. Desalination 198 (1-3) 225-235. https://doi.org/10.1016/j. desal.2006.03.517.

SABS (South African Bureau of Standards) (2015) South African National Standard 241-1:2015 Drinking water, Part 1: Microbiological, physical, aesthetic and chemical determinants. 241-2:2015 Drinking water, Part 2: Application of SANS 241-1. SABS, Pretoria.

SANAS (South African National Accreditation System) (2018) Directory of Accredited Facilities. URL: http://www.sanas.co.za/ schedules/testing/T0132-05-2018.pdf. (Accessed 6 May 2018).

SWANEPOEL A, DU PREEZ H, SCHOEMAN C, JANSE VAN VUUREN S and SUNDRAMA A (2008) Condensed laboratory methods for monitoring phytoplankton, including cyanobacteria, in South African freshwaters. WRC Report No. TT 323/08. Water Research Commission, Pretoria.

TIBCO SOFTWARE INC. (2017) Statistica (data analysis software system), version 13. URL: http://statistica.io (Accessed 20 January 2019).

WANG C, WU Y, BAI L, ZHAO Y, YAN Z, JIANG H and LIU X (2018) Recycling of drinking water treatment residue as an additional medium in columns for effective $\mathrm{P}$ removal from eutrophic surface water. J. Environ. Manage. 217 363-372. https://doi.org/10.1016/j. jenvman.2018.03.128.

ZHOU Z, YANG Y, LI X, LI P, ZHANG T, LV X, LIUC L, DONG J and ZHENGA D (2018) Optimized removal of natural organic matter by ultrasound-assisted coagulation of recycling drinking water treatment sludge. Ultrasonics Sonochem. 48 171-180. https://doi. org/10.1016/j.ultsonch.2018.05.022. 